\title{
WITHDRAWN: Exergy and Energy Analysis of a CHP System with a Gas Turbine and a Horizontal Axis Wind Turbine
}

\author{
Nima Norouzi* \\ Department of Energy Engineering and Physics, Amirkabir University of Technology (Tehran polytechnic), \\ 424 Hafez Avenue, PO Box 15875-4413, Tehran, Iran
}

Received July 19, 2021; Accepted July 24, 2021; Published August 1, 2021

This article has been withdrawn at the request of the author. The Publisher apologizes for any inconvenience this may cause.

Article copyright: (C) 2021 Nima Norouzi. This is an open access article distributed under the terms of the Creative Commons Attribution 4.0 International License, which permits unrestricted use and distribution provided the original author and source are credited. 